\section{Contributors}

lain Bamforth's two anthologies, The Body in the Library (Verso) and The Good European (Carcanet), both currently available at amazon.co.uk and make rather fine Christmas presents.

iainbamforth@orange.fr

Jeff Clark is a member of the fabulous South Bristol GP trainer's workshop who meet annually at Saunton Sands. His thoughts are guided by the German Philosopher Hans-Georg Gadamer 'Nothing exists except through language'.

jbclark@blueyonder.co.uk

\section{Mike Fitzpatrick}

fitz@easynet.co.uk

John Frey is professor of family medicine at the University of Wisconsin These days he reads more books on his IPod than on the page.

John.Frey@FAMMED.WISC.EDU

Jeremy Gibson works as a part-time GP in Ripley, Derbyshire, and part-time as a consultant in rehabilitation medicine at Derby City General Hospital. jeremygibson@doctors.org.uk

Jerome Hoffman is an old-fashioned Prof and does clinical work 12 hours week (in the Emergency Department at UCLA), has research grant support (all federal government funded) for about half his time, and spends the other 50 or 60 hours teaching and writing. jrh@ucla.edu

Patrick McEvoy is a GP at the Aberfoyle Medical Practice in Derry, Northern Ireland.

pmcevoy@tinyworld.co.uk

Lesley Morrison is a GP in in Hawick Scottish borders.

lesley@ljmorrison.fsnet.co.uk

Stuart Murray is director of postgraduate general practice education in the West of Scotland.

stuart.murray@nes.scot.nhs.uk

John Salinsky is based in London. As the creator of Norman Gland he has made us laugh for 2 years. Thanks for that, John!

JVSalinsky@aol.com

James Willis also scored $85 \%$, in a recent essay for his Open University course on 20th century English literature. (Actually Scottish literature, Lewis Grassic Gibbon's marvellous trilogy, $A$ Scots Quair.)

jarwillis@googlemail.com

Barack Obama will be the 44th President of the United States of America. His election campaign cost $\$ 650$ million. Remarkably $85 \%$ of this colossal sum came in the form of small donations of less than $\$ 200$.

http://news.bbc.co.uk/1/hi/world/amer icas/us_elections_2008/7710079.stm

Alec Logan

Depity Editor

\title{
The Light Side
}

On this year's 5 November it wasn't merely fireworks that lit up the darkness. Or that allowed the world, believing at last where it had hardly dared to hope, to finally breathe out.

I hadn't thought I would be able to bring myself to watch the results coming in. But in the end we sat up together, transfixed, as though by the image of a bomb being agonisingly disarmed, until the clinching Ohio result -2.30 a.m., our time. A few hours later we were awake again, laptop on our bedspread and watching a replay of the historic acceptance speech, morning tea choppy in the cup from my helpless sobs. Then straight out for a double bunch of flowers and a bottle of real, though moderately-priced, Sainsburys' Champagne (unexpectedly and ironically pink when we shared it with successive visitors).

People were quick with their continuing fears: he was such a target, the expectations were so high, there was so little he could actually do, the world was facing economic collapse anyway. None of this dented my euphoria - still hasn't because I worked out long ago that, especially in politics, the journey is always more important than the arrival. What matters is where you are trying to go and the direction you are travelling; getting there was always an improbable bonus, often an illusion.

And the direction of travel set forth with such eloquence and with such passion in that victory speech was the opposite of the direction of travel of the devil we knew. Here was a new statesman who seemed to combine the strengths of many worlds and who was manifestly as intelligent as he was resilient. Above all, here was a man of reason, promising a renewed enlightenment for a world that could survive hardly a second longer the perversity of its latter-day slide into ignorance.

My wife and I have just visited the National History Museum's Darwin Big Idea exhibition, on its opening morning, partly because we are devising a celebration of Darwin's double anniversary (200 for the man, 150 for the book, next year) for our little drama group. No issue is more symptomatic of the sloppy intellectual agnosticism that increasingly pervades our culture than the recent re-emergence of specious arguments about the origin of species that had for more than a century been regarded as settled.

It is urgently necessary to reiterate, for example, Thomas Huxley's great riposte to Samuel Wilberforce. In the sneering style which had earned him the nickname 'Slippery Sam', the bishop climaxed his long speech by 'begging' of his opponent 'whether it was through his grandfather or his grandmother that he claimed his descent from a monkey'. Huxley may or may not have turned to his neighbour and whispered 'The Lord has delivered him into my hands' (and the story has the ring of truth to me), but all accounts agree the gist of what he then quietly rose to say:

'I am not ashamed to have a monkey for my ancestor; but I would be ashamed to be connected with a man who used great gifts to obscure the truth.'

At this time of desperate peril for the world we are utterly dependent on science and rationality for our survival into even the short-term future. Yet increasing numbers of people, including, almost unbelievably, some of those entrusted with the teaching of science to young people, are unable to distinguish unsupported assertion and belief from a scientific theory, such as the theory of evolution, which is supported by, and consistent with, immense bodies of evidence and expertise.

In the preface to his 2006 book The Audacity of Hope, Barack Obama states bluntly that he believes in evolution, scientific enquiry, and global warming. Hallelujah! This may be some way from calling Obama by Huxley's famous nickname, 'Darwin's bulldog', but in a country a majority of whose voters question all three of these things he was elected. Hallelujah! (Forgive me, but if I had not been asked for this column at rather short notice I would at this moment be singing Messiah from Scratch in the Albert Hall). Often a doom-sayer, I am now going to rejoice in my new optimism. Where our age looked set to be dubbed by any surviving historians 'The Endarkenment', we may now, at long, long last, be turning back towards the light. Yes, yes, yes: Hallelujah!

DOI: 10.3399/bjgp08X376401 